\title{
Pengaruh Program Acara Talk Show Bugar Bersama Ade Rai Terhadap Pemenuhan Kebutuhan Informasi Pendengar Tentang Kebugaran di Radio PR 107.5 FM Kota Bandung
}

\author{
Tantan Gunawan \\ Megister Komunikasi Universitas Padjadjaran \\ tango_prima@yahoo.com
}

\begin{abstract}
This research focuses on how far the influence of the talke show Bugar Bersama Ade Rai contained in Radio PRFM Bandung in meeting the information needs of listeners about fitness. The research method used is explanatory survey method with quantitative approach and sampling technique used is accpore porpusive sampling. The population of the research were the listeners of the talk show Bugar Bersama Ade Rai in Radio PRFM Bandung and sample of the research were the listeners who often contact the announcer in the question and answer session. Technical analysis of data used is the technique of path analysis and inferential analysis used is the correlation coefficient by using Pearson correlation formula. The results showed the intensity of Talke Show Bugar with Ade Rai influenced both directly to meet the information needs of radio listeners, even indirectly through the content materials and actualization. The content of Talk Show Bugar together with Ade Rai has an effect both directly on the fulfillment of information needs of radio listeners, even indirectly through the intensity and actualization. Whereas the motive of the actualization of Talk Show listeners with Ade Rai has a good effect directly on the fulfillment of information needs radio listeners, even indirectly through the intensity and content of the material. The intensity, content and motive of the actualization of the listeners Talk. Show Fit together with Ade Rai influence together towards the fulfillment of information needs of radio listeners
\end{abstract}

Keywords: Talk Show, Radio PRFM Bandung, Fulfillment of Information Needs

\section{Abstrak}

Penelitian ini memfokuskan pada sejauhmana pengaruh acara talk show Bugar Bersama Ade Rai yang terdapat di Radio PRFM 
Bandung dalam memenuhi kebutuhan informasi pendengar tentang kebugaran.

Metode penelitian yang digunakan adalah metode survey eksplanatori dengan pendekatan kuantitatif dan teknik sampling yang digunakan adalah accindental porpusive sampling. Populasi penelitian adalah pendengar acara talk show Bugar Bersama Ade Rai di Radio PRFM Bandung dan sample penelitian adalah para pendengar yang sering menghubungi penyiar dalam sesi tanya jawab. Teknis analisis data yang digunakan adalah teknik analisis jalur dan analisis inferensial yang digunakan adalah koefisien korelasi dengan menggunakan rumus korelasi Pearson.Hasil penelitian menunjukan intensitas Talk Show Bugar bersama Ade Rai berpengaruh baik secara langsung terhadap pemenuhan kebutuhan informasi pendengar radio, mapun secara tidak langsung melalui isi materi maupun aktualisasi.Isi materi Talk Show Bugar bersama Ade Rai berpengaruh baik secara langsung terhadap pemenuhan kebutuhan informasi pendengar radio, mapun secara tidak langsung melalui intensitas maupun aktualisasi.Sedangkan motif aktualisasi pendengar Talk Show kebugaran bersama Ade Rai berpengaruh baik secara langsung terhadap pemenuhan kebutuhan informasi pendengar radio, mapun secara tidak langsung melalui intensitas maupun isi materi. Intensitas, isi materi dan motif aktualisasi pendengar Talk Show Bugar bersama Ade Rai berpengaruh bersama terhadap pemenuhan kebutuhan informasi pendengar radio.

Kata kunci :Talk Show, Radio PRFM Bandung, Pemenuban Kebutuban Informasi

\section{Pendahuluan}

Memasuki era informasi saat ini, komunikasi mengalami kemajuan pesat.Informasi dan komunikasipun saling berkaitan antara yang satu dengan yang lainnya.Peran komunikasi terjadi secara otomatis dan tanpa disadari telah mengalami suatu proses pembelajaran yang terjadinya secara timbal balik dan saling mempengaruhi. Media massa berperan penting dalam proses pembelajaran ini, sehingga dalam berinteraksi dengan orang lain penyedia media massa menerapkan komunikasi massanya dalam mempengaruhi kelompok masyarakat. Perkembangan era informasi saat 
ini memposisikan komunikasimassa sebagaisuatu proses dalam memenuhi kebutuhan manusia akan informasi.

Radio merupakan salah satu bentuk media dari komunikasi massa yang sangat populer. Penyampaikan informasi melalui radio menggunakan gelombang suara tanpa memperlihatkan bentuk visual dari pesan yang disampaikan, sehingga para pendengarnya dapat berimajinasi terhadap pesan yang mereka terima.Radio menurut Frank Jefkins dalam bukunya Public Relations, adalah "Sebuah media utama informasi, hiburan, dan pendidikan massal yang sangat populer"1.

Melalui radio, informasi merupakan hal yang menunjang berjalannya suatu radio. Hal ini senada dengan isi dan materi informasi yang disiarkan sesuai dengan kebutuhan pendengarnya. Tanpa adanya informasi sebuah radio tidak akan bisa berjalan.Informasi yang disampaikan oleh radio terdiri dari program-program yang dibuat oleh stasiun radio. Secara umum, program radio terdiri dari materi-materi pokok sebagai berikut: 1) Program-program berita, 2) Program-program siaran langsung (misalnya Talk Show), 3) Materi program rekaman dan 4) Program televisi versi radio $^{2}$.

Keberadaan stasiun radio memiliki kemudahan akses yang tidak dimiliki oleh media massa lainnya. Saat ini radio masih menjadi media favorit dan tetap eksis sebagai media siaran untuk mencari informasi bagi masyarakat luas termasuk di Kota Bandung. Hal ini karena keberadaan stasiun radio di Kota Bandung sebagai kota jasa dan pendidikan berperan strategis dalam ikut serta menyebarkan informasi dan hiburan pada masyarakatnya. Pendengar radio di Kota Bandung khususnya memiliki jumlah yang tidak sedikit.Berbagai radio memiliki tempat dihati pendengarnya.Salah satu stasiun radio yang memiliki tempat di hati pendengar masyarakat Kota Bandung yaitu PR FM karena menerapkan konsep citizen jurnalismdengan memberikan keleluasaan masyarakat Kota Bandung untuk ikut berperan serta dalam menyampaikan laporan informasi dan berinteraksi dalam setiap kegiatan penyiarannya.

Acara-acara yang disajikan PR FM dalam program siarannya dijadikan pilihan bagi pendengar yang lebih membutuhkan informasi daripada hiburan.Selain memutar lagu, radio PR FM lebih sering menyajikan berbagai acara news dan interaktif serta talk showyang selalu melibatkan peran serta interaksi pendengarnya.Interaktifitas di sini dimaksudkan selain sebagai sarana hiburannamun lebih kepada sarana

\footnotetext{
${ }^{1}$ Frank Jefkins, Public Relations (Jakarta: Erlangga, 1992), 87

${ }^{2}$ Jefkins, 89
} 
informasi dan edukasi sebagai sumber pengetahuan bagi pendengarnya.Salah satu sajian siaran interaktif yang disiarkan oleh PR FM berupa special programme berjenis Talk Showyang disajikan sesuai dengan style radio PR FM Bandung. Penting bagi PR FM Bandung untuk menjalin hubungan baik dengan khalayak eksternal terutama pendengar agar loyalitas tetap terjaga dan mampu meningkatkan tingkat kepercayaan dari para pendengarnya dengan memenuhi kebutuhan informasi pendengar terutama berkaitan dengan informasi kebugaran.Acara ini menghadirkan sosok Ade Rai sebagai narasumber yang memiliki kredibilitas dan news value dalam memberikan berbagai informasi kesehatan, yang pernah beberapa kali meraih prestasi baik nasional maupun internasional selama berkarir sebagai binaragawan. Program talk show ini menyajikan informasi bertemakan kesehatan yang perlu diketahui oleh pendengarnyadengan mengangkat topik kebugaran.Di samping itu Program Talk Show BugarbersamaAde Raiini juga dapat digunakan sebagai sarana promosi khususnya promosi yang berhubungan dengan bidang kesehatan.

Dalam Program Talk Show Bugarbersama Ade Raidi Radio PR FM, pendengar mempunyai harapan untuk dapat mendengar informasi tentang kesehatan di seputar Kota Bandung yang menarik untuk diketahui seputar kesehatan lainnya, secara interaktif "on air" yang juga seringkalididampingi oleh dokter yang bertugas. Bila harapan ini terpenuhi, maka akan meningkatkan kepuasan pendengar PR FM secara keseluruhan yang pada akhirnya akan memenuhi kebutuhan informasi pendengarPR FM tentang kebugaran. Hal inilah yang ingin dipaparkan peneliti dengan memilih judul penelitian Pengaruh Program Talk ShowBugar bersamaAde Raiterhadap Pemenuhan Kebutuhan Informasi Pendengar Tentang Kebugaran.

\section{Landasan Teori}

\section{Psikologi Kognitif Sebagai Grand Theory}

Para ahli psikologi kognitif berpendapat bahwa kita bukanlah penerima rangsangan yang pasif, otak secara aktif mengolah informasi yang diterima dan mengubahnya dalam bentuk kategori baru (Atkinson, 1987: 10). Kognisi mengacu pada proses mental dari persepsi, ingatan, dan pengolahan informasi yang memungkinkan seseorang memperoleh pengetahuan, memecahkan persoalan, dan merencanakan masa yang akan datang. Psikologi kognitif merupakan studi ilmiah mengenai kognisi. Pendekatan kognitif sebagian berkembang sebagai rekasi terhadap sempitnya pandangan S-R, pandangan yang menyatakan bahwa 
tindakan manusia semata-mata didasarkan pada stimulus dan output respons. Padahal manusia dapat berpikir, merencanakan, mengambil keputusan berdasarkan informasi yang diingat, serta memilih dengan cermat stimulus mana yang membutuhkan perhatian.

Penelitian kognitif adalah "variabel analitik" didalamnya berupaya membuat katalog variabel yang signifikan dan menunjukkan cara-cara ini berhubungan satu sama lain. Peneliti kognitif juga tertarik pada cara-cara informasi dan variabel pemrosesan yang menyebabkan hasil-hasil perilaku tertentu ${ }^{3}$.Jadi, pada tradisi kognitif, komunikasi dipahami yang berkenaan dengan pemikiran manusia secara individual. Dalam tradisi kognitif, mengkonsentrasikan pada proses mental yang menengahi antara masukan dan keluaran, antara stimulus dan respons. Teori kognitif berasumsi bahwa individu memiliki maksud dan membuat pilihan.Psikologi kognitif adalah studi tentang kognisi, tentang pemikiran atau pemrosesan informasi.

Dari teori ini jika dikaitkan dengan penyajian talk show di radio maka kegiatan penyampaian pesan berupa stimuli yang akan diterima komunikan, tidak begitu saja diterima tetapi ada pengolahan informasi yang masuk yang meliputi sensasi, persepsi, memori, dan berpikir (ada proses komunikasi intrapersonal). Dalam kaitannya dengan tujuan periklanan maka untuk sampai pada pengingatan pemirsa, harus melalui serangkaian proses komunikasi intrapersonal tersebut.

\section{Teori S-O-R sebagai Midle Range Theory}

Dalam penelitian ini menggunàkan teori Stimulus Organism Response (S-O-R) sebagai teori antara (Middle Range Theory).Teori S-O-R merupakan pengembangan dari teori psikologi Stimulus - Respons (S R) yang menunjukkan bahwa belajar hanya bisa terjadi melalui asosiasi dan pengulangan ${ }^{4}$. Tujuan sederhana dari pola ini adalah untuk memperlihatkan adanya hubungan antara stimulus dan respons sebagai penerapan $\mathrm{S}$ - R dalam komunikasi massa, menyangkut pembentukan makna baru dari kata. Makna ini bisa memberikan arti denotatif atau konotatif. Arti denotatif, mengandung makna yang diterima secara umum oleh orang yang sama budaya dan bahasanya. Sedangkan arti konotatif adalah asosiasi yang seringkali mempunyai hubungan dengan

3 Stephen W Littlejhon, Theories of Human communication $9^{\text {th }}$ ed. Terjemahan: Mohammad Yusuf Hamdan( Jakarta: Salemba Humanika, 1996), 15

${ }^{4}$ Werner J Severin \& James W. Tankard, Teori Komunikasi Sejarah, Metode dan Terapan di Dunia Media Massa, (Jakarta: Kencana Prenada Media Group, 1979), h. 192 
emosi dan pesan yang dilibatkan pada kata tersebut. Menurut Effendy ${ }^{5}$, konotatif mengandung pengertian emosional dan evaluatif yang bisa menimbulkan interprestasi yang berbeda pada komunikasi.

Dilihat dari komunikasi, teori S-O-.R menyatakan bahwa efek komunikasi adalah tanggapan spesifik terhadap rangsangan spesifik, sehingga seseorang dapat mengharapkan timbulnya kesesuaian antara pesan media dengan respon khalayak.Unsur-unsur dalam model ini yaitu pesan (Stimulus, S), komunikan (Organism, O) dan efek (Respon, $\mathrm{R})$.Biasanya keterpautan antara unsur-unsur tersebut sebagai $\mathrm{S}$--- $\mathrm{O}$---$\mathrm{R}^{6}$.

Dihubungkan dengan penelitian ini, yang diteliti adalah pengaruh kegiatan talkshow terhadap pemenuhan kebutuhan informasi. Terbentuknya suatu sikap tergantung kepada proses individu. Stimulus yang berupa pesan dalam talkshow yang disampaikan kepada komunikan mungkin diterima atau ditolak. Komunikasi berlangsung jika ada perhatian dari komunikan dan apabila komunikan mengerti pesan tersebut, sehingga ia mampu untuk menerimanya, maka diharapkan akan terjadi suatu tindakan yang lebih nyata.Dalam proses perubahan sikap konsumen dapat berubah, hanya jika stimulus dalam hal ini talkshow melalui radio siaran yang menerpa benar-benar melebihi semula.

\section{Teori Uses and Gratifications sebagai Application Theory}

Aplication Theory yang dipergunakan dalam penelitian ini adalah Teori Uses and Gratifications merupakan kritik dari teori jarum hipodermik. Teori ini pertama kali dinyatakan oleh Elihu Katz, yang menekankan bukan pada apa yang dilakukan media pada khalayak (what media do to people) tetapi pada apa yang dilakukan khalayak kepada media (what people to do media). Anggota khalyak dianggap secara aktif menggunakan media untuk memenuhi kebutuhannya ${ }^{7}$.

Teori Uses and Gratifications berguna untuk meneliti asal mula kebutuhan manusia secara psikologis dan sosial, yang menimbulkan harapan tertentu dari media massa atau sumber-sumber lain (atau keterlibatan pada kegiatan lain) dan menimbulkan pemenuhan kebutuhan lain.

\footnotetext{
${ }^{5}$ Effendy, Onong Uchjana Effendy, Dinamika Komunikasi (Bandung: Remaja Rosdakarya, 1993), 34

${ }^{6}$ Onong Uchjana Effendi, Kamus Komunikasi (Bandung: Penerbit Mandar Maju, 1989), 345-346

${ }^{7}$ Jalaluddin Rakhmat, Psikologi Komunikasi (Bandung: Remaja Rosdakarya, 2007), 
Inti teori Uses and Gratifications adalah khalayak pada dasarnya menggunakan media massa menggunakan motif-motif tertentu. Media dianggap berusaha memenuhi motif khalyak. Jika motif itu terpenuhi maka kebutuhan khalayak akan terpenuhi. Sehingga khalayak dianggap secara aktif menggunakan media untuk memenuhi kebutuhannya.Khalayak aktif dan sangata selektif menerima setiap terpaan itu.Khalayak aktif berkaitan dengan terpaan selektif."Terapan selektif artinya khalayak memilih media dan isi pesan yang mereka yakini paling sesuai dengan pandangan, pendapat dan pengalaman mereka ${ }^{8}$. Dengan kata lain khalayak akan menggunakan media yang berguna bagi dirinya. Sehingga studi dalam bidang ini memusatkan perhatiannya kepada penggunaan (uses) media untuk mendapatkan kepuasan (gratifications) atas kebutuhan khalayak.

Asumsi teori ini secara jelas menyatakan bahwa masing-masing individu dapat membawa tingkat yang berbeda-beda pada aktifitas penggunaan media.Manusia adalah agen aktif maka bersikap mengambil inisiatif. Seseorang yang ingin tertawa akan mencari saluran yang menyiarkan cerita komedi dan akan memilih saluran berita ketika ingin mencari informasi. Media dan audiensnya tidak berada dalam ruang vacuum atau bebas dari pengaruh berbagai faktor yang berada di lingkungan keduanya. Baik media maupun audiens merupakan bagian dari tatanan masyarakat yang lebih besar, hubungan antara media dan audiens dipengaruhi oleh masyarakat tersebut.Hal ini akhirnya mempengaruhi gratifikasi masyarakat terhadap kebutuhan berbagai jenis media.Seperti dalam penelitian Katz, Gurevitch dan Haas meneliti bagaimana kebutuhan masyarakat menentukan pemilihan media yang digunakan.

Kegiatan Talk Show Bugar bersama Ade Rai, dan Pemenuhan Kebutuhan informasi dengan mempergunakan pengukuran terhadap kegiatan Talk Show yang terdiri dari 1) intensitas , 2) isi media, dan 3) motif aktualisasi ${ }^{9}$.Kegiatan Talk Show Kebugaran bersama Ade Rai merupakan variabel penyebab yang dalam penelitian ini mempergunakan pengukuran pemenuhan kebutuhan informasi berupa 1) kognitif, 2) afektif, 3) intregrasi personal, 4) Intregrasi sosial dan 5) kebutuhan pelepasan $^{10}$. Penerima (komunikan) di sini khususnya adalah para

\footnotetext{
${ }^{8}$ Charles R Wright, Sosiologi Komunikasi Massa, Penyunting Jalaluddin Rakhmat (Bandung:Remadja Karya, 1985), 134

${ }^{9}$ Rakhmat, h. 66

${ }^{10}$ Alexis Tan, Mass Media : Theories and Research (Ohio: Grid.Publishing, Inc, 1981), 
pendengar radio PR FM Bandung yang pernah mendengarkan Kegiatan siaran Talk ShowBugar bersama Ade Rai.

\section{Komunikasi Massa}

Kata komunikasi atau bahasa Inggrisnya communication, berasal dan bahasa Latin, yaitu communications dan bersumber dari kata communis yang berarti "sama". Sama di sini adalah "sama makna" (lambang) (Ruslan,2005:17). Kegiatan komunikasi secara sederhana tidak hanya menyampaikan informasi, tetapi juga mengandung unsur persuasi, yakni agar orang lain bersedia menerima suatu pemahaman dan pengaruh, mau melakukan suatu perintah, bujukan dan sebagainya.

Definisi komunikasi menurut pendapat Benard Berelson dan Garry A. Stainer dalam bukunya, "Human Behavior"sebagai berikut :

"Komunikasi adalah transmisi informasi, gagasan, emosi, keterampilan, dan sebagainya dengan menggunakan simbol-simbol atau kata-kata, gambar, bilangan, grafik dan lain-lain. Tindakan atau proses transmisi itulah yang biasanya disebut komunikasi" ${ }^{11}$.

Semua peristiwa komunikasi yang dilakukan mempunyai tujuan, yakni mempengaruhi khalayak atau penerima. Pengaruh atau efek ialah perbedaan antara apa yang dipikirkan, dirasakan dan dilakukan oleh penerima sebelum dan sesudah menerima pesan ${ }^{12}$. Oleh karena itu pengaruh merupakan suatu elemen penting dalam komunikasi untuk mengetahui keberhasilan atau tidaknya kegiatan komunikasi yang dilakukan tersebut. Sehingga pengaruh dapat dikatakan pula bahwa perubahan yang terjadi sama dengan tujuan yang diinginkan oleh komunikator yang sangat ditentukan oleh sumber, pesan dan penerimanya, sebagai hasil dari komunikasi persuasif yang dilakukan.

Proses komunikasi pada awalnya dibagi menjadi dua kategori, yakni komunikasi antar personal dan komunikasi massa (Blake \& Haroldsen, seperti yang dikutip Komala, dalam Karlinah, dkk, 1999). Karakteristik komunikasi antar personal sebagai suatu proses adalah komunikator dan komunikannya tatap muka (face to face communication) dan di antara mereka terjadi saling berbagi ide, informasi dan berbagi sikap.

${ }^{11}$ Deddy Mulyana,Ilmu Komunikasi Suatu Pengantar (Bandung: Remaja Rosdakarya, 2008), 62 2002), 163

12 Hafied Cangara, Pengantar Ilmu Komunikasi Jakarta: Raja Grafindo Persada, 


\section{Boadcast/Penyiaran}

Perkembangan teknologi komunikasi telah melahirkan masyarakat yang makin besar tuntutannya akan hak untuk mengetahui dan hak untuk mendapatkan informasi. Informasi telah menjadi kebutuhan bagi masyarakat dan telah menjadi komoditas penting dalam kehidupan masyarakat. Perkembangan teknologi komunikasi dan informasi telah membawa implikasi terhadap dunia penyiaran, termasuk penyiaran di Indonesia. Penyiaran sebagai penyalur informasi dan pembentuk pendapat umum, perannya semakin strategis, terutama dalam mengembangkan kehidupan demokratis. Penyelenggaraan penyiaran tentunya tidak terlepas dari kaidah-kaidah umum penyelenggaraan telekomunikasi yang berlaku secara universal. Penyiaran mempunyai kaitan erat dengan spektrum frekuensi radio dan orbit satelit geostasioner yang merupakan sumberdaya alam yang terbatas sehingga pemanfaatannya perlu diatur secara efektif dan efisien.

Prinsip dasar teknis penyiaran yaitu jenis-jenis layanan siaran yang umumnya digunakan saat ini yang meliputi pengertian mengenai radio AM, radio FM, radio gelombang pendek (SW), televisi VHF, dan televisi UHF. Namun sebelumnya kita perlu terlebih dahulu memahami pengertian singkat mengenai siaran, penyiaran dan hal apa saja yang menjadi syarat terjadinya penyiaran. Kata "siaran" merupakan padanan dari kata broadcast dalarn bahasa Inggris. Undang-Undang Penyiaran memberikan pengertian siaran sebagai pesan atau rangkaian pesan dalam bentuk suara, gambar, atau suara dan gambar atau yang berbentuk grafis, karakter, baik yang bersifat interaktif maupun tidak, yang dapat diterima melalui perangkat penerima siaran.

Sementara penyiaran yang merupakan padanan kata broadcasting memiliki pengertian sebagai : kegiatan pemancar luasan siaran melalui sarana pemancaran dan/atau sarana transmisi di darat, di laut atau di antariksa dengan menggunakan spektrum frekuensi radio (sinyal radio) yang berbentuk gelombang elektromagnetik yang merambat melalui udara, kabel, dan atau media lainnya untuk dapat diterima secara serentak dan bersamaan oleh masyarakat dengan perangkat penerima siaran.

\section{Audiens Penyiaran}

Acara atau program apakah yang disukai oleh audien?Pertanyaan inilah yang selalu menjadi pemikiran pengelola program media nyiaran.Pertanyaan tersebut sangat sederhana namun sangat penting. Dalam kenyataannya ternyata tidaklah mudah menentukan apa yang sukai atau tidak disukai audien. Mereka yang mencari jalan pintas 
cngatakan apa yang disukai audien adalah acara-acara yang mengekloitasi sensualitas dan kekerasan. Di Indonesia, selain kedua tema tersebut, tema-tema seputar mistik juga disukai audien.

Pengelola program media penyiaran sudah tentu tidak dapat menyusun programnya menurut selera sendiri.Selera staf bagian program tidak dengan sendirinya merupakan selera masyarakat umum. Pengelola program mungkin mempunyai selera yang sangat baik bergaya dan berkelas dalam memilih suatu acara, tetapi itu bukan jaminan bahwa publik akan menyukai acara itu. Setiap siaran utamanya ditujukan untuk audien, bukan untuk penyiar, pengelola program atau pemilik media penyiaran.Penyiar radio tidak dapat memutar lagu-lagu yang menurutnya bagus berdasarkan seleranya sendiri. Mengetahui secara persis apa kebutuhan audien merupakan hal yang penting, tidak sekadar menghadirkan acara dengan materi atau kemasan baru tetapi isinya tetap yang lama. Pengelola program membutuhkan pendapat dan khalayak.Banyak media penyiaran yang sukses dijalankan oleh orangorang yang justru tidak suka pada acara-acara yang mereka tayangkan. Melakukan penelitian adalah cara terbaik untuk mengetahui keinginan audien.

Bagaimana menyeleksi audien sangat ditentukan oleh bagaimana pengelola media penyiaran melihat audien itu sendiri. Dengan demikian, audien yang dilihat oleh dua orang yang berbeda, yang didekati oleh metode segmentasi yang berbeda akan menghasilkan peta audien yang berbeda pula. Oleh karena itulah penting dipahami struktur-struktur atau kelompok-kelompok audien yang ada di tengah masyarakat. Segmentasi terbagai sebagai berikut :

1. Segmentasi Audien

Segmentasi pasar audien adalah suatu konsep yang sangat penting dalam memahami audien penyiaran dan pemasaran program.Eric Berkowitz dan rekannya mendefinisikan segmen pasar sebagai "dividing up a market into distinct groups that (1) have common needs and (2) will respond similarly to a market action ". (membagi suatu pasar ke dalam kelompokkelompok yang jelas yang (1) memiliki kebutuhan yang sama dan (2) memberikan respons yang sama terhadap suatu tindakan pemasaran). Dengan demikian, jika ditinjau dari perspektif audien penyiaran, maka segmentasi pasar adalah suatu kegiatan untuk membagi-bagi atau mengelompokkan audien ke dalam kotak-kotak yang lebih homogen ${ }^{13}$.

${ }^{13}$ Elvinaro Ardianto dan Bambang Q-Anees (Filsafat Ilmu Komunikasi. Bandung: Simbiosa Rekatama Media, 2009), 43 
Pengelola program penyiaran harus memilih sam atau beberapa segmen audien saja yang memiliki karakter atau respons yang sama dan seluruh penduduk Indonesia. Dengan memahami siapa audiennya, maka praktisi penyiaran dapat menentukan bagaimana cara menjangkaunya, program apa yang dibutuhkan, dan bagaimana mempertahankan audien dan program pesaing. Segmentasi diperlukan agar stasiun penyiaran dapat melayani audiennya seeara lebih baik, melakukan komunikasi yang lebih persuasif dan yang terpenting adalah memuaskan kebutuhan dan keinginan audien yang dituju. Untuk mempromosikan suatu program misalnya, praktisi penyiaran harus tahu siapa yang akan menjadi audiennya.

\section{Segmentasi Demografis}

Segmentasi audien berdasarkan demografi pada dasarnya adalah segmentasi yang didasarkan pada peta kependudukan, misalnya : jenis kelamin, besarnya anggota keluarga, pendidikan tertinggi yang dicapai, jenis pekerjaan konsumen, tingkat penghasilan, agama, suku, dan sebagainya. Semua ini disebut dengan variabel-variabel demografi. Data demografi dibutuhkan antara lain untuk mengantisipasi perubahanperubahan audien menyangkut bagaimana media penyiaran menilai potensi audien yang tersedia dalam setiap area geografi yang dapat dijangkau.

3. Segmentasi Audien Radio

Di Indonesia media penyiaran yang sudah sangat tersegmentasi adalah stasiun radio. Berdasarkan riset, stasiun radio di kota besar tidak dapat lagi menjadi media yang bersifat umum yang membidik seluruh lapisan masyarakat. Stasiun di kota besar harus membidik segmen secara terbatas misalnya: kalangan remaja, perempuan, kalangan bisnis, dan lainlain. Di kota besar program stasiun radio umumnya sudah tersegmentasi.Di kota kecil atau di daerah, segmentasi audien mungkin tidak lalu diperlukan karena tingkat persaingan masih sangat rendah sehingga media penyiaran cenderung masih bersifat umurn. Stasiun radio dengan segmentasi audien yang jelas pada dasarnya merniliki potensi yang sangat besar digunakan para pemasang iklan untuk mencapai konsumennya.

\section{Talkshow Radio}

Acara atau program sebagai faktor yang paling penting dan menentukan dalam mendukung keberhasilan finansial suatu stasiun penyiaran radio dan televisi. Adalah program yang membawa audien 
mengenal suatu stasiun penyiaran. Jika suatu stasiun memperoleh jumlah audien yang besar dan jika audien itu memiliki karakteristik yang dicari oleh pemasang iklan, maka stasiun bersangkutan akan sangat menarik bagi pemasang iklan. Dengan demikian, pendapatan dan keuntungan stasiun penyiaran sangat dipengaruhi oleh programnya.Tanggung jawab program dipercayakan kepada departemen program.

\section{Manajer Program}

Bagian program yang bagus biasanya terdiri dari orang-orang yang mengetahui apa yang disukai dan tidak disukai audien. Di negara-negara berkembang ternyata tidak mudah mencari staf program yang bagus. Direktur atau manajer program tergolong posisi yang paling sulit diisi karena susah untuk menemukan orang yang berpengalaman. Bagi media penyiaran lokal, kepala bagian program sebaiknya adalah seseorang yang memahami budaya lokal setempat dan cita rasa pemirsa lokal.Manajer program juga harus terus mempelajari hasil-hasil laporan riset audien untuk menentukan atau lebih mengetahui demografi audien stasiun penyiarannya pada berbagai waktu siaran serta untuk mengukur keberhasilan dan kegagalan program tertentu.Ia memiliki kewenangan untuk menentukan program apa yang akan dipilih, diproduksi atau dibeli sehingga menghasilkan kombinasi program yang menarik sepanjang hari. a. Perbincangan Radio (Talk Show)

Perbincangan radio (talk show) pada dasarnya adalah kombinasi antara seni berbicara dan seni wawancara.Setiap penyiar radio sudah semestinya adalah seorang yang pandai menyusun kata-kata.Singkatnya seorang penyiar haruslah pandai bicara.Namun penyiar yang pandai berkata-kata belum tentu bagus mewawancarai orang.Tidak semua penyiar, pandai mewawancarai orang.Apalagi menggabungkan keterampilan berbicara dengan berwawancara.

Program perbincangan biasanya diarahkan oleh seorang pemandu acara (host) bersama satu atau lebih narasumber untuk membahas sebuah topik yang sudah dirancang sebelumnya. Tiga bentuk program perbincangan yang banyak digunakan stasiun radio adalah : 1) One-on-oneshow, yaitu bentuk perbincangan saat penyiar (pewawancara) dan narasumber mendiskusikan suatu topik dengan dua posisi mikrofon terpisah di ruang studio yang sama, 2) Panel discussion, pewawancara sebagai moderator hadir bersama sejumlah narasumber dan 3) Call in show, program perbincangan yang hanya melibatkan telepon dan pendengar. Topik ditentukan lebih dahulu oleh penyiar di studio, diberikan contoh berdasarkan pengalaman penyiar, kemudian pendengar 
diminta untuk memberikan respons berdasarkan pengalaman masingmasing ke stasiun radio.Tidak semua respons audien layak disiarkan sehingga perlu petugas penyeleksi telepon masuk sebelum diudarakan.

Perencanaan produksi talk show antara lain meliputi : penentuan target pendengar yang dituju agar topik yang dipilih sesuai dengan kebutuhan pendengar, menentukan narasumber yang kompeten terhadap topik yang dibahas, memilih penyiar serta menyiapkan lokasi dan peralatan on air terutama jika siaran langsung dan lapangan.

b. Konsep dan Teori Kebugaran Jasmani

Pengertian kebugaran jasmani menurut Prof. Sutarman adalah suatu aspek, yaitu aspek fisik dan kebugaran yang menyeluruh (total fitness) yang member kesangguapan kepada seseorang untuk menjalankan hidup yang produktifdan dapat menyesuaikan diri pada tiap-tiap pembebanan fisik (physical stress) yang layak.Prof. Soedjatmo Soemowardoyo menyatakan bahwa kesegaran jasmani adalah kemempuan tubuh untuk menyesuaikan fungsi alat-alat tubuhnya dalam batas-batas fisiologi terhadap lingkungan (ketinggian, kelembapan, suhu, dan sebagainya) dan atau kerja fisik dengan yang cukup efisien tanpa lelah secara berlebihan. Secara umum pengertian kebugaran jasmani adalah kemampuan seseorang untuk menjalankan pekerjaan sehari-hari dengan ringan dan mudah tanpa merasakan kelelahan yang berarti dan mempunyai cadangan tenaga untuk melakukan kegiatan yang lain. Manfaat kebugaran jasmani bagi tubuh antara lain dapat mencegah berbagai penyakit seperti jantung, pembuluh darah, dan paru-paru sehingga meningkatkan kualitas hidup secara keseluruhan. Dengan jasmani yang bugar, hidup menjadi menjadi semangat dan menyenangkan. Kebugaran jasmani tidak hanya menggambarkan kesehatan, tetapi merupakan cara mengukur individu melakukan kegiatannya sehari-hari. ada 3 hal penting dalam kebugaran jasmani, yaitu : 1) Fisik, berkenaan dengan otot, tulang, dan bagian lemak; 2) Fungsi organ, berkenaan dengan efisiensi system jantung, pembuluh darah, dan pernfasan (paru-paru); dan 3) Respon Otot, berkenaan dengan kelenturan, kekuatan, dan kelemahan.

Berdasarkan konsep kebugaran jasmani tersebut, maka kebugaran jasmani yang dibutuhkan untuk setiap orang sangat berbeda, tergantung dari sifat tantangan fisik yang dihadapinya. Contohnya, seorang kuli yang setiap hari, memanggul barang-barang berat, maka ia harus memiliki kekuatan otot, anaerobic power, daya tahan, dan sebagainya yang lebih baik daripada seorang pekerja kantor. Pekerja kantor tidak banyak menguras tenaga, ia hanya membutuhkan buku- 
buku dari meja ke rak buku atau menekan tombol-tombol keyboard computer. Dengan demikian tingkat kebugaran jasmani yang mereka miliki dan mereka butuhkan sangat berbeda.

Hipotesis

Berdasarkan latar belakang masalah, identifikasi masalah, tujuan penelitian, landasan teori dan kerangka pemikiran, maka hipotesis yang ditetapkan dalam penelitian ini adalah :

1. Terdapat pengaruh intensitas kegiatan talk show terhadap pemenuhan kebutuhan informasi pendengar tentang kebugaran

2. Terdapat pengaruh isi media kegiatan talk show terhadap pemenuhan kebutuhan informasi pendengar tentang kebugaran

3. Terdapat pengaruh motif aktualisasi kegiatan talk show terhadap pemenuhan kebutuhan informasi pendengar tentang kebugaran.

\section{Hasil Penelitian}

Pengaruh Intensitas Tak Show Kebugaran bersama Ade Rai terhadap Pemenuhan Kebutuhan Informasi Pendengar tentang Kebugaran

Hasil pengujian statistik menunjukkan bahwa Ho ditolak (signifikan), sehingga dapat dinyatakan bahwa intensitas Talk ShowBugar bersama Ade Rai berpengaruh parsial secara signifikan terhadap pemenuhan kebutuhan informasi pendengar PR FM Bandung. Hasil pengujian hipotesis ini memperlihatkan bahwa peningkatan intensitas Talk Show Bugar bersama Ade Rai berpengaruh terhadap peningkatan kebutuhan informasi pendengarnya.

Hasil analisis jalur menunjukkan pula bahwa intensitas Talk Show kebugaran bersama Ade Rai berpengaruh baik secara langsung terhadap pemenuhan kebutuhan informasi pendengar radio, mapun secara tidak langsung melalui isi media maupun aktualisasi. Besarnya pengaruh langsung dan tidak langsung intensitas Talk Show Bugar bersama Ade Rai terhadap kebutuhan informasi pendengar PR FM Bandung yaitu sebesar $4,70 \%$.

Rakhmat ${ }^{14}$ yang mengutip pendapat Katz, Blumler dan Gurevitch yang mengemukakan beberapa asumsi dasar teori Uses and Gratification. Salah satunya adalah dalam proses komunikasi massa banyak inisiatif untuk mengaitkan pemuasan kebutuhan dengan pemilihan media terletak pada anggota khalayak. Hal ini memperlihatkan bahwa pendengar sebagai anggota khalayak lebih memilih media radio untuk memenuhi kebutuhan

${ }^{14}$ Rakhmat., 205 
akan informasi, atau dengan kata lain bahwa pendengar Radio PR FM Bandung memilih media radio ini dalam memenuhi kebutuhan informasi kesehatan yang diperoleh dengan mengikuti acara Talk ShowBugar bersama Ade Rai.

Durasi acara talk show Kebugaran bersama Ade Rai di radio PR FM, adalah 90 menit. Frekuensi adalah satu minggu satu kali yakni setiap hari Kamis, pukul 19.00 - 20.30. Menurut Morissan ${ }^{15}$, di Indonesia stasiun radio di kota besar tidak dapat lagi menjadi media yang bersifat umum yang membidik seluruh lapisan masyarakat. Stasiun di kota besar harus membidik segmen secara terbatas misalnya, kalangan remaja, perempuan, kalangan pebisnis dan lain-lain. Di kota kecil atau daerah, segmentasi audien mungkin tidak terlalu diperlukan karena tingkat persaingan masih sangat rendah sehingga media pentiaran cenderung masih bersifat umum. Radio PR FM di kota Bandung, menurut wawancara peneliti dengan Basith (wakil pemimpin redaksi PR FM), target audien radio ini adalah eksekutif muda. Dari hasil penelitian yang diperoleh, jam siaran acara talk show Kebugaran bersama Ade Rai dilihat dari data responden, pendengarnya adalah kalangan mahasiswa. Yakni dengan usia $20-24$ tahun. Dilihat dari waktu penyiaran, ini pun merupakan waktu mahasiswa mendengarkan program radio.

Kebutuhan integrasi personal, yaitu kebutuhan yang berkaitan dengan peneguhan kredibilitas, kepercayaan, stabilitas dan status individual. Dari hasil penelitian, menunjukkan bahwa durasi 90 menit talkshow juga penayangan satu kali dalam tiap minggu, tidak menunjukkan pengaruh signifikan bagi pendengar dalam memenuhi kebutuhan integrasi sosial. Dengan kata lain durasi acara talk show 90 menit yang disiarkan satu minggu sekali tidak membuat pendengar merasa lebih bertambah kredibilitas, kepercayaan, stabilitas dan status individualnya.

\section{Pengaruh Isi MateriTalk ShowBugar bersama Ade Rai terhadap Pemenuhan Kebutuhan Informasi Pendengar tentang Kebugaran}

Hasil pengujian statistik menunjukkan bahwa Ho ditolak (signifikan), sehingga dapat dinyatakan bahwa isi media Talk ShowBugar bersama Ade Rai berpengaruh parsial secara signifikan terhadap pemenuhan kebutuhan informasi pendengar PR FM Bandung. Hasil pengujian hipotesis ini memperlihatkan bahwa peningkatan isi media Talk Show Bugar bersama

${ }^{15}$ Morrisan, Manajemen Media Penyiaran: Strategi Mengelola Radio dan Televisi (Jakarta: Remaja Rosdakarya, 2008), 182 
Ade Rai berpengaruh terhadap peningkatan kebutuhan informasi pendengarnya.

Hasil analisis jalur menunjukkan pula bahwa isi media Talk Show Bugar bersama Ade Rai berpengaruh baik secara langsung terhadap pemenuhan kebutuhan informasi pendengar radio, mapun secara tidak langsung melalui intensitas maupun aktualisasi. Besarnya pengaruh langsung dan tidak langsung isi media Talk Show Bugar bersama Ade Rai terhadap kebutuhan informasi pendengar PR FM Bandung yaitu sebesar $75,60 \%$.

Isi media Talk Show Bugar bersama Ade Rai terdiri dari kejelasan informasi, struktur kelengkapan informasi, dan aktual/tidaknya informasi pada kegiatan komunikasi yang dilakukan oleh PR FM Bandung dalam menyuguhkan acara berkaitan dengan penginformasian kesehatan kepada pendengarnya. Upaya peningkatan isi media acara Talk Show Kebugaran bersama Ade Rai mampu meningkatkan pemenuhan kebutuhan pendengar Radio PR FM Bandung.

Informasi kebugaran dalam acara Talk ShowBugar bersama Ade Rai, dibagi menjadi enam segmen.Setiap segmen terdiri dari 12 menit, yang masing-masing diselang oleh jeda iklan. Selain iklan, jeda juga diisi dengan berita lain yang disampaikan oleh pendengar radio, sesuai dengan moto radio PR FM sebagai Citizen Journalism.

Target audien dari acara Talk Show Kebugaran bersama Ade Rai adalah pendengar usia 25 - 35 tahun. Untuk itu format acara yang disajikan harus bisa mengakomodasi kebutuhan audiennya.Hal ini memperlihatkan bahwa format acara yang disajikan telah sesuai dengan kebutuhan audien karena topik yang diangkat dalam acara talk show ini mengikuti tren kebugaran yang sedang berlangsung, sehingga isi media yang disuguhkan pada acara talk show Bugar bersama Ade Rai mampu memenuhi kebutuhan informasi pendengarnya berkaitan dengan kesehatan.Pernyataan ini dapat dilihat dari jawaban responden mengenai susunan program acara yang mudah diingat dan dipahami. Salah satu karakter radio sebagai media massa adalah daya rangsang yang rendah. Format acara yang diibuat menjadi 6 segmen masing-masing 12 menit membuat pendengar lebih mudah memahami dan mengingat materi talk show.

Hovland dalam $\operatorname{Tan}^{16}$ mengatakan bahwa sumber berkredibilitas tinggi menghasilkan banyak perubahan opini. Kredibilitas sumber dapat dilihat dari beberapa indikator, yakni : keahlian, kepercayaan, dan

16 'Tan., 80 
kemampuan untuk disukai audien. Dilihat dari prestasi yang telah diperoleh Ade Rai, maka dapat disimpulkan bahwa sumber dalam acara Talk Show Kebugaran bersama Ade Rai adalah sumber yang memiliki keahlian, dapat dipercaya audien dan memiliki kemampuan untuk disukai pendengar.

Isi media dalam penelitian ini adalah susunan, materi, musik latar, gaya bicara, topik acaraserta kesimpulan acara talk show. Hal ini sesuai dengan Morrisan ${ }^{17}$, menyatakan bahwa setiap program siaran harus mengacu pada pilihan format siaran tertentu seiring makin banyaknya stasiun penyiaran dan makin tersegmennya audien. Format siaran diwujudkan dalam bentuk prinsip-prinsip tentang apa, untuk siapa, dan bagaimana proses pengolahan suatu siaran hingga dapat diterima audien. Berdasarkan format siaran tersebut, maka talk show ini secara prinsip mengenai informasi kebugaran.

Dengan melihat hasil penelitian, maka format acara, pembawa acara, maupun nara sumber pada acara talk show kebugaran bersama Ade Rai telah berhasil menarik perhatian para pendengarnya untuk tetap mendengarkan dan menyukai acara talk show tersebut. Menurut Thompson (1960) dalammelaporkan bahwa orang lebih mudah mengingat pesan yang tersusun daripada yang tidak tersusun.

\section{Pengaruh Motif Aktualisasi Talk ShowBugar bersama Ade Rai terhadap Pemenuhan Kebutuhan Informasi Pendengar tentang Kebugaran}

Hasil pengujian statistik menunjukkan bahwa Ho ditolak (signifikan), sehingga dapat dinyatakan bahwa motif aktualisasi pendengar Talk Show kebugaran bersama Ade Rai berpengaruh parsial secara signifikan terhadap pemenuhan kebutuhan informasi pendengar PR FM Bandung. Hasil pengujian hipotesis ini memperlihatkan bahwa peningkatan motif aktualisasi pendengar Talk Show kebugaran bersama Ade Rai berpengaruh terhadap peningkatan kebutuhan informasi pendengarnya.

Hasil analisis jalur menunjukkan pula bahwa motif aktualisasi pendengar Talk Show kebugaran bersama Ade Rai berpengaruh baik secara langsung terhadap pemenuhan kebutuhan informasi pendengar radio, mapun secara tidak langsung melalui intensitas maupun isi media. Besarnya pengaruh langsung dan tidak langsung motif aktualisasi pendengan Talk Show bersama Ade Rai terhadap kebutuhan informasi pendengar PR FM Bandung yaitu sebesar 18,36\%.

17 Morrisan., 220 
Aktualisasi diri adalah kebutuhan naluriah pada manusia untuk melakukan yang terbaik dari yang dia bisa. Maslow dalam Arianto ${ }^{18}$, menyatakan aktualisasi diri adalah proses menjadi diri sendiri dan mengembangkan sifat-sifat dan potensi psikologis yang unik. Aktualisasi diri akan dibantu atau dihalangi oleh pengalaman dan oleh belajar. Aktualisasi diri akan berubah sejalan dengan perkembangan hidup seseorang. Ketika mencapai usia tertentu (adolensi) seseorang akan mengalami pergeseran aktualisasi diri dari fisiologis ke psikologis ${ }^{19}$.

Ahli jiwaAbraham Maslow, dalam bukunya Hierarchy of Needs menggunakan istilah aktualisasi diri (self actualization) sebagai kebutuhan dan pencapaian tertinggi seorang manusia.Maslow menemukan bahwa tanpa memandang suku asal-usul seseorang, setiap manusia mengalami tahap-tahap peningkatan kebutuhan atau pencapaian dalam kehidupannya. Kebutuhan tersebut meliputi:

a. Kebutuhan fisiologis (physiological), meliputi kebutuhan akan pangan, pakaia, dan tempat tinggal maupun kebutuhan biologis,

b. Kebutuhan keamanan dan keselamatan (safety), meliputi kebutuhan akan keamanan kerja, kemerdekaan dari rasa takut ataupun tekanan, keamanan dari kejadian atau lingkungan yang mengancam,

c. Kebutuhan rasa memiliki, sosial dan kasih sayang (social), meliputi kebutuhan akan persahabatan, berkeluarga, berkelompok, interaksi dan kasih sayang,

d. Kebutuhan akan penghargaan (esteem), meliputi kebutuhan akan harga diri, status, prestise, respek, dan penghargaan dari pihak lain,

e. Kebutuhan aktualisasi diri (self actualization), meliputi kebutuhan akan memaksimumkan penggunaaan kemampuan dan potensi diri.

Berdasarkan uraian di atas dapat dikatakan bahwa aktualisasi diri merupakan suatu proses menjadi diri sendiri dengan mengembangkan sifat-sifat serta potensi individu sesuai dengan keunikannya yang ada untuk menjadi kepribadian yang utuh. Motif aktualisasi pendengar Talk Show Bugar bersama Ade Rai merupakan aktualiasai diri pendengar dalam mengikuti kegiatan yang dilakukan oleh PR FM Bandung dalam menyuguhkan acaranya.Upaya peningkatan aktualisasi pendengar acara Talk Show Kebugaran bersama Ade Rai mampu meningkatkan pemenuhan kebutuhan pendengar Radio PR FM Bandung.

18 Elvinaro Ardianto \& Bambang Q-Anees, Filsafat Ilmu Komunikasi (Bandung: Simbiosa Rekatama Media, 2009)

${ }^{19}$ Ardianto, 2009 
Motif aktualisasi di sini, materi dalam talk show itu sesuai dengan kebutuhan yang pendengar perlukan. Menurut Maslow dalam $\operatorname{Tan}^{20}$, salah satu teori umum mengenai masyarakat dan media massa adalah teori bierarchy of needs. Dalam teori kebutuhan dan motivasi ini, Maslow menyatakan bahwa manusia secara aktif mencari pemenuhan kebutuhan disatu tingkat atau level, barulah orang itu akan bergerak untuk memenuhi kebutuhan pada tingkat berikutnya. Berdasarkan hierarchy of needs tersebut, pendengar talkshow ini mempunyai kebutuhan pada tingkat self actualization.Jadi mereka memerlukan informasi yang dapat memberikan kesempatan kepada mereka untuk mengaktualisasikan diri.

Aktualisasi diri pertama kali dicetuskan oleh Kurt Goldstein yang kemudian mengacu pada motif diri yang bertujuan menggali potensi diri.Aktualisasi diri juga diartikan sebagai (keinginan) menjadi diri sendiri.Dalam penelitian ini, motif diri pendengar untuk mendapatkan informasi menngenai kebugaran dari acara talk show Kebugaran bersama Ade Rai, berdasarkan jawaban yang diberikan pendengar melalui kuisioner dapat terpenuhi.

\section{Pengaruh bersama Intensitas, Isi Media dan Motif Aktualisasi Talk ShowBugar bersama Ade Rai terhadap Pemenuhan Kebutuhan Informasi Pendengar tentang Kebugaran}

Hasil pengujian statistik menunjukkan bahwa Ho ditolak (signifikan), sehingga dapat dinyatakan bahwa intensitas, isi media dan motif aktualisasi pendengar Talk Show kebugaran bersama Ade Rai berpengaruh bersama secara signifikan terhadap pemenuhan kebutuhan informasi pendengar PR FM Bandung. Hasil pengujian hipotesis ini memperlihatkan bahwa peningkatan intensitas, isi media dan motif aktualisasi pendengar Talk Show Bugar bersama Ade Rai berpengaruh terhadap peningkatan kebutuhan informasi pendengarnya.Hasil analisis jalur menunjukkan pula bahwa intensitas, isi media dan motif aktualisasi pendengar Talk Show kebugaran bersama Ade Rai berpengaruh bersama terhadap pemenuhan kebutuhan informasi pendengar radio. Besarnya pengaruh secara bersama intensitas, isi media dan motif aktualisasi pendengar Talk Show bersama Ade Rai terhadap kebutuhan informasi pendengar PR FM Bandung yaitu sebesar 98,70\%.

Intensitas, isi materi dan motif aktualisasi pendengar Talk Show Bugar bersama Ade Rai merupakan kegiatan komunikasi yang dilakukan oleh PR FM Bandung dalam menyuguhkan acaranya.Upaya peningkatan 
intensitas, isi media dan motif aktualisasi acara Talk ShowBugar bersama Ade Rai secara bersama mampu meningkatkan pemenuhan kebutuhan pendengar Radio PR FM Bandung.Hasil ini juga memperlihatkan bahwa isi media Talk Show Bugar bersama Ade Rai memiliki pengaruh terbesar terhadap pemenuhan kebutuhan pendengar Radio PR FM Bandung, kemudian motif aktualisasi pendengar, dan pengaruh terkecil yaitu intensitas.

Pendengar radio memiliki kebutuhan untuk memenuhi informasi tentang kesehatan, dan ternyata isi media memiliki pengaruh terbesar dibandingkan aktualisasi diri dan intensitas acara. Melalui acara talk showBugar bersama AdeRai kebutuhan pemenuhan infotmasi ini dapat terpenuhi dikarenakan isi media yang disuguhkan oleh Radio PR FM Bandung. Dengan melihat hasil yang didapat, maka isi media acara talk show ini paling besar dalam memenuhi kebutuhan pemenuhan informasi kesehatan para pendengarnya.

\section{Penutup}

Kesimpulan

Kesimpulan dalam penelitian ini adalah sebagai berikut :

a. Intensitas Talk Show kebugaran bersama Ade Rai berpengaruhbaik secara langsung terhadap pemenuhan kebutuhan informasi pendengar radio, mapun secara tidak langsung melalui isi media maupun aktualisasi.

b. Isi media Talk Show kebugaran bersama Ade Rai berpengaruh baik secara langsung terhadap pemenuhan kebutuhan informasi pendengar radio, mapun secara tidak langsung melalui intensitas maupun aktualisasi.

c. Motif aktualisasi pendengar Talk Show kebugaran bersama Ade Rai berpengaruh baik secara langsung terhadap pemenuhan kebutuhan informasi pendengar radio, mapun secara tidak langsung melalui intensitas maupun isi media.

d. Intensitas, isi media dan motif aktualisasi pendengar Talk Show kebugaran bersama Ade Rai berpengaruh bersama terhadap pemenuhan kebutuhan informasi pendengar radio.

Saran

Saran yang dapat peneliti sampaikan berdasarkan penelitian ini adalah sebagai berikut :

a. Untuk lebih meningkatan kegiatan talkshow pada Radio PR FM 107.5 News Channel Bandung dapat, mendorong pendengar untuk secara aktif memberikan masukan pada prorgam-program yang sudah dijalankan 
b. Peningkatan partisipasi masyarakat dalam acara atau kegiatan yang diadakan Radio PR FM 107.5 News Channel Bandung, kepuasan yang diberikan Radio PR FM 107.5 News Channel Bandung sudah sangat baik dan perlu untuk mempertahankannya selain itu pemerintah lebih giat membantu pelaksanaan program-program yang akan dilakukan Radio PR FM 107.5 News Channel Bandung.

c. Untuk penelitian lebih luas dan lebih rinci diusahakan dimasukkan variabel lain selain intensitas, isi media dan aktualisasi yang berpengaruh terhadap pemenuhan kebutuhan infotmasi kesehatan untuk mendapatkan hasil yang lebih maksimal.

\section{Daftar Kepustaka}

Ardianto, Elvinaro \& Bambang Q-Anees. 2009. Filsafat Ilmu Komunikasi. Bandung: Simbiosa Rekatama Media.

Azwar, Saifuddin. 2011. Sikap Manusia Teori dan Pengukurannya. Yogyakarta: Pustaka Pelajar Offset.

Bungin, Burhan. 2009. Sosiologi Komunikasi. Jakarta: Kencana Prenada Media Group.

Cangara, Cangara. 2002. Pengantar Ilmu Komunikasi. Jakarta: Raja Grafindo Persada

DeVito. 1991. Human Communication $5^{\text {th }}$ ed., New York: Harper Collins Publishers Inc.

Effendy, Onong Uchjana. 1989. Kamus Komunikasi. Bandung: Penerbit Mandar Maju.

Effendy, Onong Uchjana. 1993. Dinamika Komunikasi. Bandung: Remaja Rosdakarya.

Fisher, B. Aubrey. 1986. Teori-Teori Komunikasi. Bandung: Remaja Rosdakarya.

Jefkins, Frank Jefkins. 1992.Public Relations. Jakarta: Erlangga

Littlejhon, Stephen. W. 1996. Theories of Human communication $9^{\text {th }}$ ed. Terjemahan: Mohammad Yusuf Hamdan. Jakarta: Salemba Humanika.

Mar'at, Prof.DR. 1982. Sikap Manusia Perubahan serta Pengukuran. Bandung: Ghalia Indonesia. 
Miles, Mathew B. \& Huberman. 1992. Buku Sumber Tentang Metode-Metode Baru, Jakarta: UI Press.

Morrisan. 2008. Manajemen Media Penyiaran: Strategi Mengelola Radio dan Televisi. Jakarta: Remaja Rosdakarya

Muller, Craig. 2007. Theorizing Communication: Readings Across Traditions, California: Sage Publications.

Mulyana, Deddy. 2008. Ilmu Komunikasi Suatu Pengantar. Bandung: Remaja Rosdakarya.

Rakhmat, Jalaludin. 2007. Psikologi Komunikasi. Bandung: Remaja Rosdakarya.

Severin, Werner J \& James W. Tankard. 1979. Teori Komunikasi Sejarah, Metode dan Terapan di Dunia Media Massa. Jakarta: Kencana Prenada Media Group.

Soemirat, Soleh. 2000. Komunikasi Persuasif. Jakarta: UT Depdiknas.

Soerjono, Soekanto. 1999. Sosiologi, Suatu Pengantar. Jakarta: Rajawali Pers.

Sugiyono,. 2010. Statistika untuk Penelitian. Bandung. Alfabeta.

Susanto, Astrid. 1983. Pengantar Sosiologi dan Perubahan Sosial. Jakarta: Binacipta.

Sztompka, Piotr. 1993. Sosiologi Perubahan Sosial. Jakarta: Prenada Media Group.

Tan, Alexis. 1981. Mass Media : Theories and Research. Ohio: Grid.Publishing, Inc.

Tubbs, Stewart L \& Moss, Sylvia. 1996. Human Communication : Prinsip-Prinsip Dasar. Terjemahan : Deddy Mulyana. Bandung: Remaja Rosdakarya.

Wright, Charles R . 1985. Sosiologi Komunikasi Massa, Penyunting Jalaluddin Rakhmat. Bandung:Remadja Karya 